https://doi.org/10.18778/8220-645-6.09

MACIEJ KWIATKOWSKI

(UNIWERSYTET W BIAEYMSTOKU)

\title{
SZTUKA MELORECYTACJI STUDIA NAD GENEZĄ MUZYKI RAP
}

Streszczenie. Artykuł jest poświęcony problematyce związanej z początkiem muzyki rap. Studiowanie najstarszych utworów pokazuje, że w większości przypadków, ludzie rapowali dla zabawy albo by zachęcić innych do uczestnictwa w tej formie interakcji. Autor bada nie tylko pierwsze utwory i rapowych artystów, ale także pochodzenie, które wynikło z inspiracji kilkoma gatunkami muzycznymi, jak blues, funk, czy jazz. Analiza paru singli z lat 70. i 80. próbuje odpowiedzieć na pytanie, co stało za popularnością danych brzmień. Przez swoją specyfikę, tekst pośrednio dotyka kulturę miejską Nowego Jorku ubiegłego wieku, w Stanach Zjednoczonych.

Słowa kluczowe: przeszłość, geneza, kultura, rap, scratch.

\section{Wstęp}

$\mathrm{P}$ otrzeba napisania poniższego artykułu wynika z przekonania, że w umysłach wielu osób rap pozostał niezbadaną częścią historii. Postawa ta wynika z faktu, iż omawiany gatunek muzyczny należy wciąż do najpopularniejszych na świecie, natomiast z racji datowania pierwszych utworów, utrzymanych w klimacie rapu, niewiele współczesnych ludzi ma możliwość opowiedzenia o początkach zjawiska. Dodatkowo, kiedy powstawał, kontakty kulturowe między Polską oraz Stanami Zjednoczonymi były mocno ograniczone. Rozważania będą dotyczyły przede wszystkim datowania istotnych wydarzeń i korzeni muzyki rap. Mniej miejsca poświęcimy dla samego zjawiska społecznego, które przybrało na sile w latach 70 . ubiegłego wieku w Stanach Zjednoczonych, o ile nie będzie to potrzebne w uświadomieniu czytelników. Niewątpliwie musimy wspomnieć o kulturze hip-hop. Autor zdaje sobie sprawę z ogromu materiału, którego mogą dotyczyć rozważania, 
ze wskazaniem na różne państwa. W takim wypadku kluczowe jest zbadanie macierzy, a więc prehistorii gatunku, czyli Stanów Zjednoczonych Ameryki.

Poniższe wyniki badań przede wszystkim mają za zadanie wskazać, co wpłynęło na całokształt omawianego gatunku muzycznego, do roku 1980. Ustalenie tejże daty granicznej wynika z ważnego epizodu, jakim było uzyskanie pierwszego statusu złotej płyty, dla artysty czynnie wykonującego rap. Ów certyfikat jest zarazem wyraźnym sygnałem, iż specyficzna forma artyzmu dotarła do szerszego grona odbiorców i tym samym mamy do czynienia ze zjawiskiem masowym.

\section{Źródła}

Specyfiką niniejszej pracy będzie szeroki zakres źródeł muzycznych. Zostały one zaprezentowane $\mathrm{w}$ przypisach według schematu: autor, nazwa piosenki ${ }^{1}$, wytwórnia, rok wydania ścieżki dźwiękowej. W kontekście omawianego zagadnienia, kluczowe wydają się pojedyncze utwory, często opublikowane w ramach winylowych singli. Oczywiście staramy się prześledzić również treść niektórych albumów długogrających. Jesteśmy w stanie dotrzeć do nagrań, ocierających się o rap z lat $50 .^{2}$ oraz $60 .^{3}$ Ciekawy przykład melorecytacji dostarczył nam znany bokser Muhammad Ali, w ramach swojego muzycznego odpowiednika ${ }^{4}$ Utwór autorstwa Gilla Scott-Herona wyraźnie pokazuje, że zwykłe wypowiadanie słów, może być istotną częścią produkcji ${ }^{5}$. Nietypowe akcentowanie treści znajdziemy przy okazji odsłuchu piosenki Curtisa Mayfielda ${ }^{6}$. Utworem, na którym zakończymy omówienie muzyków, którzy próbowali swoich sił w rapowaniu, ale nie byli profesjonalnymi wykonawcami tego gatunku, jest produkcja autorstwa Fatback Band ${ }^{7}$.

Wreszcie oddzielną kategorię stanowią samplowane kompozycje, z których niekiedy korzystali raperzy. Omawiana kwestia dotyczy zwłaszcza utworów, które powstały po 1979 roku .

${ }^{1} \mathrm{~W}$ niniejszej pracy czytelnik może spotkać się z paroma synonimami tego słowa, tj. muzyką, trackiem, beatem, utworem. Podobnie sprawa wygląda z raperami (wokalista, wykonawca, przedstawiciel, MC).

2 C. Berry And His Combo, Too Much Monkey Business, Chess Record Corp., 1956.

${ }^{3}$ P. Markham, Here Comes The Judge, Chess Producing Corp., 1968.

${ }^{4}$ C. Clay, Round 1: „I Am the Greatest”, [w:] I Am the Greatest, Columbia Records, 1963.

${ }^{5}$ G.S. Heron, The Revolution Will Not Be Televised, BGP, 1971.

${ }^{6}$ C. Mayfield, Pusherman, [w:] Superfly, Curtom Records, 1972.

7 Fatback Band, King Tim III, Spring Records, 1979; ściśle rzecz ujmując, autor ma na myśli, iż Fatback Band nie był stricte rapowym zespołem, natomiast faktycznie do współpracy zaprosili zawodowego rapera.

${ }^{8}$ Chic, Good Times, Atlantic Recording Corporation, 1979. 
Względem drugiego rozdziału, skorzystamy ze ścieżek dźwiękowych, które wykonali czynni raperzy. Niestety, zbadanie tego zagadnienia jest utrudnione, przez brak istnienia legalnie wydawanych materiałów muzycznych, z gatunku rap, aż do 1979 roku. Wiemy natomiast, że niektórzy rzeczywiście organizowali imprezy, na których odtwarzano pewne piosenki. Zwracają na to uwagę sami artyści. Pośrednio poświadczają o tym plakaty, bądź bilety na koncerty, w tym także po wydaniu kilku legalnych produkcji, po 1979 roku9. Co istotne, możemy również skorzystać z kilku ówczesnych nagrań na żywo ${ }^{10}$.

Wydaje się, że pierwszym, pełnoprawnym utworem z gatunku muzyki rap, był singiel Sugarhill Gangu ${ }^{11}$, wydany kilka miesięcy po premierze utworu Fatback Band. Nie znamy dokładnej daty wydania kilku utworów z 1979 roku, takich reprezentantów jak The Younger Generation ${ }^{12}$ Spoonin $\mathrm{Gee}^{13}$, czy Funky Four Plus One More ${ }^{14}$, jednak mnogość tych produkcji świadczy o rosnącej popularności gatunku. W sumie z lat 1979-1980 możemy znaleźć kilkadziesiąt różnych utworów, ale prezentacja ich wszystkich mija się z celem pracy. W 1980 roku Spoonie Gee, wraz z The Threacherous Three wydał kolejny track, wyraźnie nawiązujący do przedmiotu niniejszych studiów ${ }^{15}$. Wypada również wspomnieć o debiucie pierwszej kobiecej grupy, nagrywającej dla wytwórni Sugar Hill Records ${ }^{16}$.

${ }^{9}$ R. James/Grandmaster Flash Kansas City Concert Poster, 1976, https://entertainment. ha.com/itm/music-memorabilia/posters/rick-james-grandmaster-flash-kansas-city-concert-poster-al-haymon-1976-/a/7011-51068 (dostęp: 8.09.2020); R. Laurence, 40 years on from the party where hip hop was born, https://www.bbc.com/culture/article/20130809the-party-where-hip-hop-was-born (dostęp: 3.09.2020); Bronx River Center, May 30, 1980, https://digital.library.cornell.edu/catalog/ss:1335161 (dostęp: 3.09.2020).

10 Grand Wizard Theodore, Mean Gene, Live on 3rd Avenue-Ballroom, 1977, https://www. youtube.com/watch?v=jw3CqFzcOfM (dostęp: 9.09.2020); Grandmaster Flash \& The 4 MCs, Live at the Audubon Ballroom, 1978; https://www.youtube.com/watch?v=AupuYHEo2p0 (dostęp: 9.09.2020). Warto jednak z pewną dozą ostrożności badać wspomniane nagrania. Nie wiemy, czy rzeczywiście przedstawiają one muzykę z danego okresu, bowiem w przeciwieństwie do płyt, datowanie pozostawało w gestii nieoryginalnych autorów, którzy opublikowali owe nagrania kilkanaście lat później.

11 Sugarhill Gang, Rapper's Delight, Sugarhill Records, 1979.

12 The Younger Generation, We Rap More Mellow, Brass Records, 1979.

${ }^{13}$ Spoonin Gee, Sound of New York A Soulful Sound: Spoonin Rap, Queen Constance Records, 1979.

14 Funky Four Plus One More, Rapping and Rocking The House, Enjoy Records, 1979.

15 Spoonie Gee and The Threacherous Three, The New Rap Language, Enjoy Records, 1980.

16 The Sequence, Funk You Up, Sugarhill Records, 1979; Spoonie Gee, Spoonie Gee Meets The Sequence, Monster Jam, Sugar Hill Records, 1980. 
Na zakończenie rozdziału, swoją uwagę skupimy na analizie tracku, autorstwa Kurtis Blowa ${ }^{17}$. Prócz zapisu muzycznego, zanalizujemy kilka plakatów i ulotek bezpośrednio dotyczących tematu pracy. Ich obserwacja dodatkowo pozwoli obserwatorowi na wgłębienie się w omawianą problematykę.

\section{Literatura}

Poszczególne pozycje przede wszystkim pełnią funkcję pomocy naukowej. Z drugiej strony to właśnie bardziej współczesne prace są w stanie ocenić zjawisko, jakim było powstanie rapu, w większym stopniu podążając do upragnionego obiektywizmu. Możemy odnieść wrażenie, że kompleksowe studia, w stylu encyklopedii są w przypadku badanego tematu najważniej$\mathrm{sze}^{18}$. W tym wypadku uzasadnione wydaję się skorzystanie także $\mathrm{z}$ anglojęzycznej formy objaśniania pewnych zjawisk ${ }^{19}$. Bardzo interesujący przykład opracowania popełnił Ed Piskor, przedstawiając całe zjawisko kultury hip-hop w formie komiksu ${ }^{20}$. Poszczególne elementy tych prac, w ramach opisu niektórych postaci potrafią dostarczyć ciekawych, choć zapewne nie zawsze sprawdzonych informacji. Interesujące dla czytelnika może być przedstawienie poszczególnych odmian, omawianego gatunku muzycznego. Autor ma zamiar zasygnalizować odpowiednik rapu, spoza Stanów Zjednoczonych ${ }^{21}$.

Powstało kilka filmów, których nie powinniśmy lekceważyćc2 ${ }^{2}$. Wydaję się, że dociekliwi czytelnicy mogą zainteresować się kulisami muzyki, od strony biznesowej, w tym samego zarobkowania dzięki muzyce ${ }^{23}$. W ten sposób prześledzimy historię powstawania pierwszych wytwórni, specjalizujących się w wydawaniu omawianego gatunku. Przedstawione w artykule zagadnienia obracają się wokół czarnoskórej społeczności, więc podejrzewamy, iż nakreślenie zjawiska czarnoskórego nacjonalizmu będzie konieczne ${ }^{24}$.

17 Kurtis Blow, The Breaks, Mercury Records, 1980.

18 A. Buda, Encyklopedia Hip-Hopu, 2005; R. Miszczak, A. Cała, Beaty Rymy Życie: Leksykon Muzyki Hip-Hop, Poznań 2005.

${ }_{19}$ A.K. Harrison, C.E. Arthur, The Foundations of Hip-Hop Encyclopedia, Blacksburg 2019; F. Muray, M.A. Neal, That's The Joint! The Hip-Hop Studies Reader, Nowy Jork 2004.

20 E. Piskor, Hip Hop Genealogia, cz. 1, Warszawa 2018.

${ }^{21}$ T. Riggs., African Hip-Hop, [w:] The St. James Encyclopedia of Hip Hop Culture, Farmington Hills 2018.

22 D. Wheler, R. Bascuñán, Ewolucja Hip-Hopu: Początek, Netflix 2016; T.L. Marrow, Something From Nothing: The Art of Rap, 2012; D. Pray, Scratch, 2001.

${ }^{23}$ D. Charnas., The Big Payback: The History of the Business of Hip-Hop, Nowy Jork 2011; D. Sköld, A. Rehn, Makin' It, by Keeping It Real: Street Talk, Rap Music, and the Forgotten Entrepreneurship „From The Hood”, „Group \& Organization Management” 2007, t. 37, nr 1.

${ }^{24}$ E.A. Henderson, Black Nationalism and Rap Music, „Journal of Black Studies” 1996, t. 26, nr 3 . 
W mniejszym stopniu będziemy posiłkować się tytułami, które narastające socjologiczne problemy, zgromadzone wokół muzyki ${ }^{25}$. Książka autorstwa Paula Edwardsa pełni pomocniczą rolę w pracy ${ }^{26}$. Solidnym dopełnieniem literatury niechaj będzie słownik angielsko-polski, który tłumaczy niektóre wyrazy używane na co dzień przez społeczność obracającą się wokół kultury hip-hip ${ }^{27}$.

\section{Prekursorzy i najstarsze źródła, dotyczące omawianego zagadnienia. Poruszając się po meandrach rapu niezaangażowanego}

Poniższy rozdział ma za zadanie przybliżyć czytelnikowi czynniki, które wpłynęły na brzmienie muzyki rap w latach 70. i 80., na przykładzie ludzi niekoniecznie związanych z tą materią dźwiękową. Rap niezaangażowany jest rozumiany jako ten, który faktycznie spełnia wymogi rytmicznej wypowiedzi w takt grającego w tle beatu. Z drugiej strony dany utwór muzyczny niekoniecznie przynależy do kultury hip-hop i nie jest wykonywany przez zawodowych raperów. W tym wypadku raczej mówimy o formie zabawy muzycznej, w której odchodzimy od klasycznej formy ekspresji wokalisty w muzyce, czyli śpiewu. Bardzo często takie niecodzienne wykonywanie pracy piosenkarza, jest charakterystyczne dla jazzmanów, ludzi kojarzonych z popem, czy funkiem ${ }^{28}$.

Pierwszym z omawianych artystów, według porządku chronologicznego jest Chuck Berry ${ }^{29}$. Bardzo ważne jest, że możemy w sposobie wykonywania przez niego utworu, znaleźć nietypową formę wypowiedzi, która ociera się o rap. Utwór składa się z siedmiu zwrotek i refrenów o takiej samej liczbie ${ }^{30}$. Podczas realizowania danej zwrotki, muzyka przycisza się, praktycznie nie słyszymy uderzającego werbla. Przedziwna intonacja tyczy się również samego Chucka Berry'ego. Wydaje się, że wykonawca nie śpiewa, a mówi. Na dodatek zwrotki są recytowane w rytmiczny sposób. Twórca ułożył tekst według klasycznego monorymu, w którym dominują rymy męskie. Z tego powodu utworowi niedużo brakuje do rapu, który uformował się dwie dekady później.

${ }^{25}$ W tym wypadku choćby zjawisko mizogini; R. Weitzer, C.E. Kubrin, Misogny in Rap Music: A Content Analysis of Prevalence and Meanings, „Men and Masculinites” 2009, t. 12, nr 1; E.G. Armstrong, Gangsta Misogyny: A Content Analysis of The Portrayals of Violence Against Women In Rap Music, 1987-1993, „Journal of Criminal Justice and Popular Culture” 2001, t. 2, nr 8, https://web.archive.org/web/20120920054843/http://www.albany.edu/scj/jcjpc/vol8is2/ armstrong.html (dostęp: 12.11.2020).

${ }^{26}$ P. Edwards, How to Rap: The Art \& Science of the Hip-Hop MC, Chicago 2009.

27 P. Ratajczak, Hip-Hop: słownik angielsko-polski, Zielona Góra 2006.

${ }^{28}$ Mówimy oczywiście o trzech, odrębnych gatunkach muzycznych.

${ }^{29}$ C. Berry And His Combo, dz. cyt.

30 Tamże. 


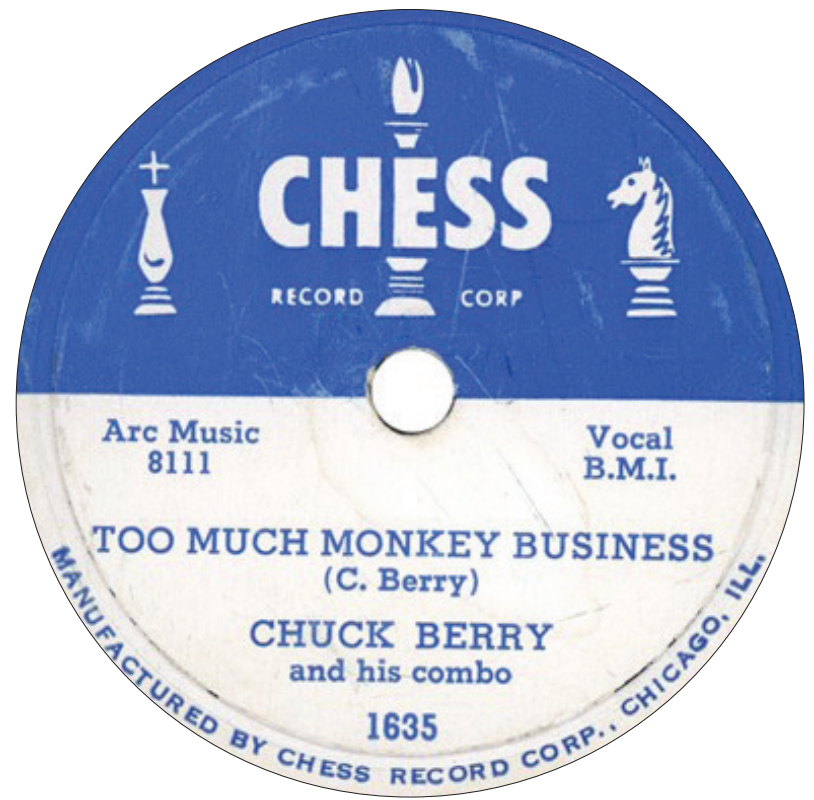

Fot. 1. Singiel Chucka Berrego z 1956 r. Czy w kontekście omawianego zagadnienia, początków muzyki rap, faktycznie możemy nazwać go nowatorskim?

Źródło: http://www.45worlds.com/78rpm/record/1635 (dostęp: 8.10.2020)

Utwór boksera Muhammada Alego, używającego wówczas imienia Cassius Clay, na płycie I Am The Greatest pozbawiony jest ścieżki dźwiękowej ${ }^{31}$. Występ głównego bohatera nagrania polega na deklamacji 32 wersów, czyli 8 zwrotek. Jego rola polega na wychwalaniu własnych zdolności, co czyni w nieraz zabawny sposób. Ową atmosferę podkreślają dograne do tracku śmiechy rzekomo zgromadzonej publiczności ${ }^{32}$. Dzięki popełnieniu I Am The Greatest, Cassius Clay stworzył podwaliny pod braggadacio, czyli formę artyzmu, polegającą na wznoszeniu własnych umiejętności, w konfrontacji z innymi, często jedynie potencjalnymi postaciami ${ }^{33}$. Popis Claya miał w przyszłości także zdefiniować stronę audiowizualną bitew freestylowych.

W przypadku Here Comes The Judge trudno mówić jednoznacznie o śpiewie. Także ten utwór jest przesiąknięty komizmem. Składa się z 28 wersów, które zostały nierówno podzielone w ramach zasadniczo 2 zwrotek $^{34}$.

\footnotetext{
31 C. Clay, dz. cyt.

32 Ów zabieg jest charakterystyczny dla sitcomów, w ramach korzystania z laugh tracków, czyli gotowych nagrań ze śmiechem.

${ }_{33}$ P. Edwards, dz. cyt., s. 25-27.

${ }^{34}$ P. Markham, dz. cyt.
} 
Całość okraszona jest funkowym brzmieniem, na co wskazuje rytmiczna perkusja oraz dźwięki gitary elektrycznej. Podczas poszczególnych przerw w rapowaniu, mają miejsce dialogi między tytułowym „sędzią" oraz bohaterami drugoplanowymi. Przytoczmy jedną z kwestii. Wygląda ona w następujący sposób:

Judge: Order, order in this courtroom

Woman: Judge, your honorship. Hi, sir

Did I hear you say order in the court?

Judge: Yes, I said ORDER

Woman: Well, I'll take two cans of beer, please ${ }^{35}$.

Dialog prowadzi do zabawnej konkluzji, gdzie słowo „order” możemy przetłumaczyć jako swoiste wezwanie do wypowiedzenia postanowienia sędziego. Drugie znaczenie oznacza zamówienie. Klarownie widzimy to w przypadku ostatniej kwestii (dosłowny przekład brzmi: „W takim razie poproszę dwie puszki piwa").

Popis Deweya Pigmeata Markhama nie był notowany na amerykańskich listach Billboard. Za to utwór uzyskał rozgłos poza obszarem Stanów Zjednoczonych. Według Official Charts Company, utwór Here Comes The Judge dotarła do 19 miejsca na liście singli i znajdowała się na niej przez 8 tygo$\mathrm{dni}^{36}$. Piosenka Pigmeat Markhama jest o tyle ważna, iż w przyszłości wpłynęła na dwie kwestie:

1. Charakterystyczne brzmienie muzyki funk stanie się inspiracją do stworzenia wielu beatów dla przyszłych raperów.

2. Rymowanie może opierać się o zabawę, wraz z uczestnictwem bohaterów drugoplanowych.

Dzieło Gilla Scotta-Hernona ma diametralnie inny wydźwięk ${ }^{37}$. Choć pozornie muzyka wykorzystana w tracku ma pozytywny wydźwięk, studiowanie poszczególnych wersów zmienia wizerunek autora i jego twórczości. Przesłuchując piosenkę od razu rzuca się w oczy arytmiczność skonstruowanego tekstu. W związku z tym liczenie wersów nie ma sensu. Niewiele pod płaszczykiem nieregularności schowane jest sedno popełnienia ścieżki dźwiękowej. Możemy odnieść wrażenie, że utwór wprost namawia do

35 Tamże.

36 Official Singles Chart Results Matching: Here Comes The Judge, https://www.officialcharts.com/search/singles/here\%20comes\%20the\%20judge/ (dostęp: 16.09.2020).

37 G.S. Heron, dz. cyt. 
rewolucji, bądź przestrzega nią społeczeństwo. Względem uchwycenia stosunku Gilla Scotta-Herona do przepowiadanego zjawiska, nasze zadanie jawi się jako ciężkie. W utworze wielokrotnie możemy usłyszeć słowa tytułowego wykonawcy, który powtarza: The Revolution Will Not Be Televised (Rewolucja nie będzie emitowana przez telewizję). Sens utworu wiele lat później wyjaśnił sam autor, w filmie z ok. 1989 roku. Wymowa piosenki polega na tym, iż rewolucja, która nadejdzie, wpierw wykiełkuje w umysłach ludzi, lecz nie będziemy w stanie jej uchwycić. Tak rozpowszechnione i wydawałoby się potężne narzędzie jakim była telewizja, ma poważne trudności w zarejestrowaniu owego procesu, wręcz jest to niemożliwe ${ }^{38}$.

Jak więc widzimy, sensem popełnienia powyżej wynotowanego utworu, była chęć przekazania wiadomości. Prawdopodobnie jako słuchacze powinniśmy samodzielnie doszukiwać się owego przesłania, na co pośrednio wskazuje celowy brak zastosowania wyraźnej rytmiki tekstu. Badanie The Revolution Will Not Be Televised może nam zasugerować, iż tekst głównego wokalisty jest najważniejszy w piosence. Właśnie przekaz utworów stanie się w latach 80. istotą występów raperów.

Curtis Mayfield również nie stronił od zajmowania się poważnymi zagadnieniami. Pusherman jest częścią soundtracku, do filmu o tym samym tytule ${ }^{39}$. Warstwę liryczną skonstruowano na podstawie ok. 42 wersów, bez refrenów. Warstwa wokalna ociera się o śpiew, z drugiej strony umiejscowienie jej w realiach rapowania zdaje się problematyczne. Odrzucenie jednej, bądź drugiej wersji nie musi być słuszne. Oczywiście możemy skupić się na falsetowym tonie Mayfielda, ale badanie problemu w ten sposób jest działaniem drugoplanowym. Zapewne przysłuchiwanie się sztuce wokalnej również jawi się jako intrygujące, jednak podobnie jak w przypadku Gilla Scotta-Herona, wydaję się, iż artysta zachęca nas do zagłębienia się w następną warstwę wątku ścieżki dźwiękowej. Musimy mieć brać pod rozwagę profesję, którą wykonywał wcielający się w przypisaną mu rolę artysta. Tytułowy Pusherman, jest handlarzem narkotyków. Faktyczna wymowa piosenki jest przypuszczalnie nieuchwytna dla badacza. Odczucia mogą być ambiwalentne:

1. Główny bohater ścieżki dźwiękowej śmieje się, biorąc pod uwagę, że ma władzę nad wieloma hipotetycznymi postaciami, oferując im narkotyki.

2. Potencjalnie artysta kpi ze społecznego wyobrażenia losu dilera.

${ }^{38}$ S. Blumberg, The ,90 raw: Gill Scott-Heron, https://mediaburn.org/video/the-90s-rawgil-scott-heron/ (dostęp: 16.09.2020).

${ }^{39}$ C. Mayfield, $d z$. cyt. 
Niezależnie od opowiedzenia się przy jednej, bądź drugiej wersji Pusherman pokazuję dobitnie, iż tematem utworów nie muszą być wyłącznie komediowe sfery. Stworzony przez Mayfielda album Superfly, na czele $\mathrm{z}$ analizowaną muzyką okazał się sporym sukcesem, docierając do 1 miejsca na liście Billboard i spędził na niej w sumie 46 tygodni $^{40}$. Pierwsza zwrotka została w 1988 roku zsamplowana przez Traycego Laurena Marrowa, na użytek wydanego wówczas singla I'm Your Pusher ${ }^{41}$.

W przytoczonych wyżej piosenkach zauważyliśmy, iż wyraźnie pokierowanie słuchacza nie było odosobnione. Co jednak zrobić w sytuacji, gdy ścieżka dźwiękowa nie ma wyraźnie zaznaczonej tematyki? Przykładem takiej muzyki jest track autorstwa The Fatback Band ${ }^{42}$. W 1979 roku zaprosili oni do współpracy rapera Tima Washingtona ${ }^{43}$. Rapujący artysta namawia do tańca, utwór ma zatem typowo dyskotekowy charakter. W piosence The Fatback Bandy nie znajdziemy wzniosłych przenośni. Wszystko obraca się wokół zabawy na parkiecie. Nieraz King Tim III wykrzykuje: „To the break everybody" lub słyszymy użyte w przyszłej twórczości Afrika Bambaaty zawołanie „Party people" 4 .

Analiza wszystkich powyższych źródeł pozwala nam wysnuć wniosek, iż rap, zaprezentowany przez twórców mógł wpasować się w kilka ram: warstwę komediową, w której śmieszyła konstrukcja wersów, wokalizacja artysty, bądź komentowano aktualne $\mathrm{w}$ danym okresie wydarzenia polityczne, poprzez poetyckie metafory. Rapowanie mogło być także zabawą, w której wokalista starał się nakłonić publiczność do uczestnictwa na dyskotekach, podczas koncertów na żywo. Przypuszczalnie sam fakt rymowania się danych wersów jawił się jako atrakcyjny. Dodatkowe okraszenie warstwy lirycznej humorem pozwalało lepiej zapamiętać tekst i przełamywało barierę na linii artysta-słuchacz. Zbytnia powaga podczas popisów muzycznych teoretycznie również nie musiała być zła, ale widzimy, że połączenie wyżej wymienionych cech, skonstruowanych w konwencji rap, trafiło w gusta odbiorców, względnie zainteresowało tę grupę. Fakt ten wynika przede wszystkim z racji określania badanych piosenek, jako jedne z pierwszych, w których wykonawca faktycznie rapował ${ }^{45}$.

40 Billboard 200, Chart History, Curtis Mayfield, https://www.billboard.com/music/curtismayfield/chart-history/TLP/song/376012 (dostęp: 17.09.2020).

${ }^{41}$ T.L. Marrow, I'm Your Pusher, Sire Records Company, 1988.

${ }^{42}$ Fatback Band, King Tim III, Spring Records, 1979.

${ }^{43}$ E. Piskor, Hip-Hop Genealogia, cz. 1, dz. cyt., s. 37.

${ }^{44}$ Afrika Bambaataa, dz. cyt.

45 Przykładowo, magazyn XXL o działalności Pigmeata Markhama, https://www.xxlmag. com/did-pigmeat-markham-release-the-first-hip-hop-song/ (dostęp: 16.09.2020). 


\section{Podmioty uczestniczące w kulturze hip-hop. Rola DJ-ów i mistrzów ceremonii, czyli rap zaangażowany}

Rozdział pierwszy miał zaprezentować czytelnikowi pierwsze próby mówienia a nie śpiewania wersów, wraz z zarysowaniem tematu ścieżek dźwiękowych i samej muzyki. Powinniśmy jednak podkreślić, iż zaprezentowani artyści popełniali analizowane piosenki, w ramach wariacji muzycznej. Nie możemy określić ich jako typowych wykonawców muzyki rap. Były to raczej pierwsze, nieśmiałe próby wypracowania nowego gatunku.

W refleksji nad disc jokeyami, pojawia się dość naturalne pytanie: kto był pierwszym DJ-em, przynależnym do hip-hopu? Wielu jako pierwszego wymienia DJ Kool Herca ${ }^{46}$. Stworzył on technikę, zwaną merry-go-round ${ }^{47}$. Polega ona na użyciu dwóch płyt winylowych, położonych bezpośrednio na oddzielnych gramofonach. Wykorzystuje się nagrania o podobnych tempie, bez zarysowanej części wokalnej, zarazem bardzo rytmicznych, czyli tzw. breaków ${ }^{48}$.

Istnieją problemy z ustaleniem pierwszego artysty, czynnie rapującego. Możemy domyślać się, że pierwszym lub jednym z pierwszych raperów mógł być nieznany z imienia człowiek, posługujący się pseudonimem Coke La Rock. Być może technika omówionego już po krótce turnbalisty były na tyle pochłaniające, że zaprosił on do współpracy właśnie Coke La Rocka ${ }^{49}$.

Jesteśmy $\mathrm{w}$ stanie przedstawić $\mathrm{w}$ poniższej pracy nagranie występu Grand Wizard Theodora, które pochodzi przypuszczalnie z 1977 roku $^{50}$. Jako młodzieniec, przypadkiem odkrył scratchowanie ${ }^{51}$. Jeżeli dzieło faktycznie pochodzi z 1977 roku, możemy śmiało wskazać je jako dowód na to, iż faktycznie odbywały się pewne imprezy, na których kształtowała się odrębna muzyka.

${ }^{46}$ D. Wheler, R. Bascuñán, dz. cyt.; E.A. Henderson, dz. cyt., s. 310; A. K. Harrison, C.E. Arthur, dz. cyt., s. 64.

47 E. Piskor, dz. cyt., s. 5.

${ }^{48}$ R. Miszczak, A. Cała, dz. cyt., s. 23-24; A. Bennett, Hip-Hop am Main, Rappin' on the Tyne: Hip-Hop Culture as a Local Construct in Two European Cities, [w:] M. Forman, M.A. Neal, dz. cyt., s. 178.

49 D. Wheler, R. Bascuñán, dz. cyt.; D. Hebdige, Rap and Hip-Hop: The New York Connection, [w:] M. Forman, M.A. Neal, dz. cyt., s. 224.

${ }^{50}$ Grand Wizard Theodore and Mean Gene, dz. cyt., https://www.youtube.com/watch?v =jw3CqFzcOfM (dostęp: 9.09.2020).

51 E. Piskor, dz. cyt., s. 5. Możemy domniemywać, że doszło do tego latem 1975 roku, zob. A. Buda, dz. cyt., s. 75. 


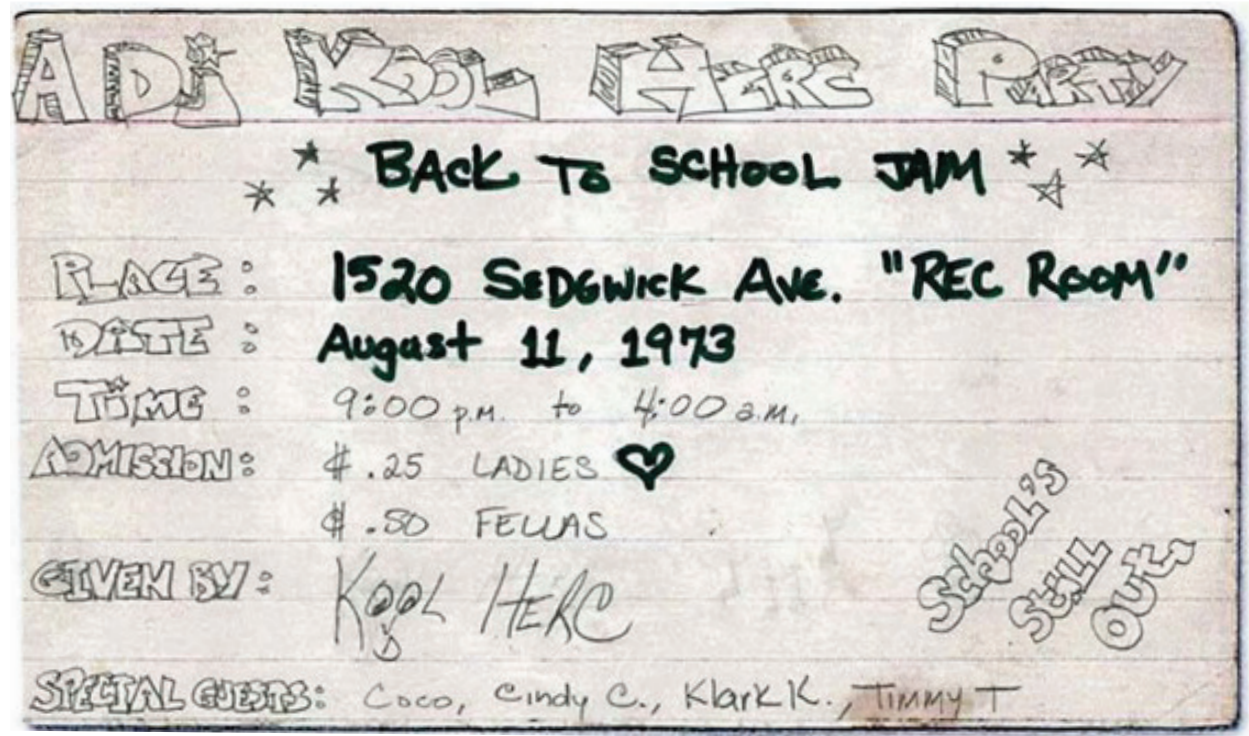

Fot. 2. Zaproszenie na prawdopodobnie pierwszą imprezę, zorganizowaną przez Dj Kool Herca 11 VIII 1973 r. Część strony graficznej przekazu potwierdza także wcześniejsze kontakty DJ Kool Herca z graffiti ${ }^{52}$

Źró dło: R. Laurence, 40 years on from the party where hip hop was born, https://www.bbc.com/culture/article/20130809-the-party-where-hip-hop-was-born

(dostęp: 3.09.2020)

Osobą, cieszącą się niewyobrażalnie wielkim autorytetem jest Grandmaster Flash. Bez wątpienia jego występy były znane już w latach 70. ubiegłego wieku. Potwierdza do szereg opracowań ${ }^{53}$. W przypadku źródeł niepisanych, do których udało się dotrzeć autorowi czytanej w tym momencie pracy, powinniśmy wykazać się roztropnością. Jednym z takich przekazów jest zapis audio koncertu, którego hipotetycznie możemy oszacować na 23 grudnia 1978 roku $^{54}$. Ważne jest, iż Flash zasłynął ze scratchowania ludzkiego głosu $^{55}$.

${ }^{52}$ N. George, Hip-Hop's Founding Fathers Speak The Truth, [w:] M. Forman, M.A. Neal, dz. cyt., s. 46.

${ }^{53}$ N. George, Hip-Hop's Founding Fathers Speak The Truth, [w:] M. Forman, M.A. Neal, dz. cyt., s. 45-46; E.A. Henderson, $d z$. cyt., s. 59; A.K. Harrison, C.E. Arthur, dz. cyt., s. 28; A. Buda, dz. cyt., s. 75-77.

${ }^{54}$ Grandmaster Flash \& The 4 MCs, Live at the Audubon Ballroom, 1978, https://www. youtube.com/watch?v=AupuYHEo2p0 (dostęp: 9.09.2020).

${ }_{55}$ A. Buda, dz. cyt., s. 75. 
Godne zapamiętania jest, że raperzy i disc jockeye zaczynali tworzyć muzykę z niczego. Właśnie ci ludzie zaczęli przeszukiwać i selekcjonować utwory, których słuchali ich rodzice. Były to tracki z pogranicza funku czy soulu $^{56}$. Oczywiście twórcy prezentowali coś odrębnego: umiejętności nietypowego puszczania muzyki czy rapowania. Natomiast początkowo utwory, do których tańczyli ludzie, pochodziły od różnych wykonawców i nie były tworzone samodzielnie, od początku do końca, przez przedstawicieli hip-hopu.

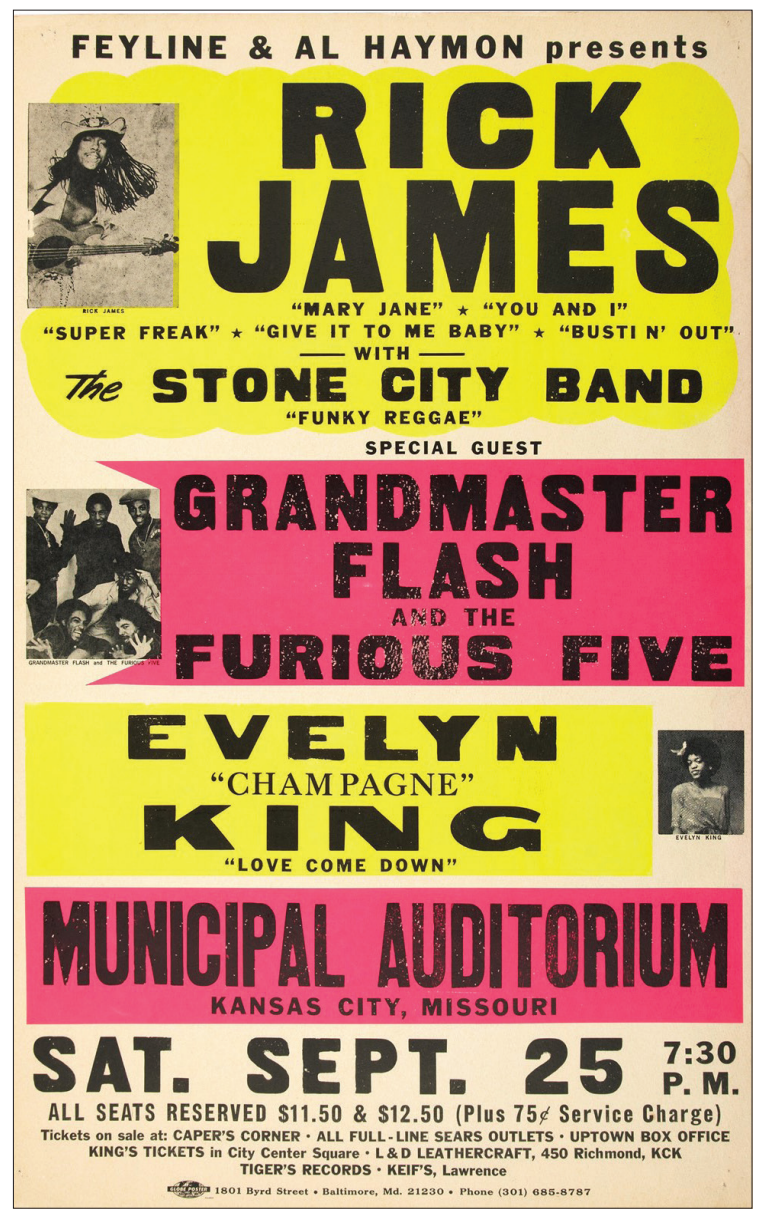

Fot. 3. Plakat promujący koncert Grandmaster Flasha, ok. 25 IX 1976 r.

Źró dło: Rick James/Grandmaster Flash Kansas City Concert Poster, https://entertainment. ha.com/itm/music-memorabilia/posters/rick-james-grandmaster-flash-kansas-cityconcert-poster-al-haymon-1976-/a/7011-51068.s (dostęp: 28.09.2020)

${ }^{56}$ Wypowiedź Grandmaster Cuza, [w:] T.L. Marrow, Something From Nothing: The Art of Rap, 2012. 
Fundamentalnym, legalnie wydanym utworem reprezentującym muzykę rap jest Rapper's Delight ${ }^{57}$. Zapewne żadnym zaskoczeniem dla słuchacza będzie wybór stylu muzycznego, który preferowali wykonawcy. W utworze możemy usłyszeć trzy, odmienne style muzyczne. Już pierwsze słowa uwidaczniają utożsamianie się wykonawcy z kulturą hip-hop. Uwagę obserwatora powinna przykuć także powaga początku pierwszej zwrotki: rap przestał być bezrefleksyjnym wykrzykiwaniem do mikrofonu ${ }^{58}$.

Debiut Sugarhill Gangu okazał się wielkim sukcesem muzycznym. W samych Stanach Zjednoczonych miał sprzedać się w 2 milionowym nakładzie ${ }^{59}$. Warto odnotować, że swój wkład w powstanie tracku miał również Grandmaster Caz, który napisał tekst. Warstwę liryczną wykorzystał później Big Bank Hank ${ }^{60}$. W takim wypadku praca zespołu nie była w pełni samodzielna. Niewątpliwie twórców należy zaliczyć do pierwszych, którzy w legalny sposób wydali rapowy singiel.

Rok 1979 oferował wiele unikatowych nagrań, związanych z rapem. Światło dzienne ujrzał choćby singiel grupy The Younger Generation We Rap More Mellow ${ }^{61}$. Pozornie track na pierwszy rzut oka może nie wyróżniać się w szczególny sposób, spośród wielu, które zadebiutowały w roku 1979. Musimy jednak podkreślić kilka czynników, dlaczego źródło znalazło się w poniższej pracy:

- Formacja The Younger Generation jako pierwsza użyła słowa MC (Master of Ceremony): That the five MCs are definitely here ${ }^{62}$,

- Cowboy, członek grupy uchodzi za pierwszego, który wymyśla termin hip-hop ${ }^{63}$.

Utwór jest raczej przykładem muzyki, dedykowanej do grania w klubach. Stylistyka ociera się o braggadacio. Dość zabawny jest fakt, że The Younger Generation w rzeczywistości nazywali się The Furious Five. Zmiana wynikała z woli producentów, którzy sądzili, że nowa marka zespołu zabrzmi lepiej i szybciej się przyjmie ${ }^{64}$.

57 Sugarhill Gang, dz. cyt.

58 Sugarhill Gang, dz. cyt.

59 A. Buda, dz. cyt., s. 194.

${ }^{60}$ Świadczy o tym fragment tekstu: „Check it out, I'm C-A-S-AN, the O-V-A and the rest is F-L-Y". Casanova Fly była pierwszym pseudonimem, używanym przez Grandmaster Caza: Zob.: Piskor E., Hip-Hop Genealogia, cz. 1, dz. cyt., s. 36.

61 The Younger Generation, $d z$. cyt.

62 Tamże.

${ }^{63}$ E. Piskor, $d z$. cyt., s. 15.

64 Tamże, s. 43. 
Mniej więcej w tym samym czasie zadebiutował również Gabriel Jackson, czyli Spoonin Gee z grupy The Threacherous Three ${ }^{65}$. Punktem wyjścia do wypuszczenia singla było doświadczenie wujka Jacksona, Paula Winleya. Krewny Sponniego Gee w tamtym okresie reprezentował wytwórnię Winley Records, którą założył. W piosence możemy usłyszeć kilka interesujących wersów, takich jak:

See I'mma roll my barrel and keep the bullets still And when I shoot my shot, I'm gonna shoot to kill

Niewybrednie brzmiące słowa możemy zdefiniować jako pierwsze wśród omawianego gatunku muzycznego, przypominające pogróżki, znane z gangsta rapu. Track oferuje także kilka zabawnych spostrzeżeń, takich jak rada, by nie upuszczać mydła: „And please my brother, don’t drop the soap” ${ }^{66}$.

Trudno w sposób zdecydowany określić, dlaczego Gabriel Jackson zdecydował się rozpocząć karierę samodzielnie. W każdym razie, choć Spoonie Gee wystąpił w tracku jako solowy artysta, w następnym roku nagrał swój kolejny popis muzyczny wraz z macierzystym składem, The Threacherous Three $^{67}$.

Dotychczas zaprezentowane piosenki zostały wykonane przez przedstawicieli płci męskiej. Nie możemy jednak całkowicie wykluczyć kobiet $\mathrm{z}$ uczestnictwa $\mathrm{w}$ rapowaniu. Taka wizja narracji historycznej byłaby działaniem niezgodnym z prawdą. Zainteresowani dziejami muzyki rap, wyodrębniliby zespół Funky Four Plus One More, jako ten, w którym brała udział reprezentantka płci pięknej. Faktycznie, Sha-Rock ${ }^{68}$ jest jedną z bohaterek początków rapu. Otwarciem dla jej kariery muzycznej razem z resztą składu, było wypuszczenie singla Rappin and Rocking The House ${ }^{69}$. Strona tekstowa nie wyróżnia się wyraźnie spomiędzy innych dzieł muzycznych. Artyści podobnie jak The Young Generation (a właściwie The Furious Five) scharakteryzowali się jako MC’s i zachęcają do tańca ${ }^{70}$. Bezsprzecznie czytelnika nie zaskoczy fakt, iż piosenka jest wręcz zanurzona w funku.

Sha-Rock nie jest jedyną kobietą, która zajęła się w sposób profesjonalny rapem, w początkowej fazie gatunku. W 1979 roku swoje pierwsze kroki sceniczne stawiała grupa The Sequence. W skład trójki wchodziły: Angie

\footnotetext{
${ }^{65}$ Spooning Gee, dz. cyt.

66 Tamże.

${ }^{67}$ Spoonie Gee and The Threacherous Three, dz. cyt.

${ }^{68}$ Właściwie Sharon Green.

${ }^{69}$ Funky Four Plus One More, dz. cyt.

70 Tamże.
} 
Brown Stone, jako Angie B, Cheryl Cook, która przyjęła pseudonim Cheryl The Pearl i Gwendolyn Chisolm, używająca nazwy Blondie. Co ciekawe, zespół nie wywodził się z Nowego Jorku, ale reprezentował miasto Carolina. Trio, składające się w całości z kobiet zadebiutowało za sprawą wytwórni Sugarhill Gang ${ }^{71}$. Widzimy więc, że dzałalność wytwórni Sylvii Robinson nie ograniczała się tylko do nieoficjalnej stolicy muzyki rap. Muzyka przyjęła się na tyle dobrze, iż w 1980 roku połączyły one siły z już przedstawionym Spoonie $\mathrm{Gee}^{72}$. Całe nagranie przypomina konwersację, momentami romantyczną, pomiędzy zespołem The Sequence a Gabrielem Jacksonem.

W tym miejscu wyprzedzając nieco wydarzenia muszę wdać się w krótką polemikę Piotrem Ratajczakiem. Dyskusja odnosi się do raczej ogólnego wyobrażenia, dotyczącego rapu. Według tego zapatrywania, środowisko raperów jawi się jako źle ustosunkowane do płci pięknej. Twórca tytułu Hip-Hop słownik angielsko-polski snuje wniosek, jakoby przedmiotowe traktowanie kobiet stoi na porządku dziennym i pogarda wobec nich jest „Dość powszechna"73. Poza prywatną opinią autora, nie pokusił się on na poparcie swojej tezy żadnymi badaniami statystycznymi, w oparciu o źródła muzyczne. Wspólna praca Ronalda Weitzera i Charisy E. Kubriny starała się uszczegółowić ów problem ${ }^{74}$. Zagraniczni twórcy we wspólnym artykule pokrótce nakreślili problematykę: W środowisku socjologów i dziennikarzy pokutuje przekonanie o wywyższaniu się raperów, wobec jednoczesnego umniejszania roli kobiet. Często panie miały być sprowadzane do roli podmiotów, które miały spełniać choćby seksualne żądze mężczyzn. Ronald Weizter i Charisa E. Kubrin, w oparciu o 403 utwory, pochodzące z albumów studyjnych, które sprzedały się w przynajmniej platynowym nakładzie i debiutowały w latach 1992-2000, snują odmienny wiosek. Uważają oni, iż jedynie $22 \%$ spełniają kryterium mizoginii ${ }^{75}$.

Identyczny procentowo rezultat wyliczeń dla wszystkich analizowanych tracków, wynikały ze studiów Edwarda G. Armstronga ${ }^{76}$. Naukowiec pokusił się o zbadanie mizogini w przedziale lat 1987-1993 na jeszcze większej grupie reprezentantywnej. W tym zestawieniu najmniej korzystnie wypada

71 The Sequence, $d z$. cyt.

72 Spoonie Gee Meets The Sequence, $d z$. cyt.

73 Tamże, s. 19.

${ }^{74}$ R. Weitzer, C.E. Kubrin, dz. cyt., s. 1-5.

75 Tamże, s. 12.

${ }^{76}$ E.G. Armstrong, Gangsta Misogyny: A Content Analysis of The Portrayals of Violence Against Women In Rap Music, 1987-1993, „Journal of Criminal Justice and Popular Culture" 2001, t. 2, nr 8, https://web.archive.org/web/20120920054843/http://www.albany.edu/scj/ jcjpc/vol8is2/armstrong.html (dostęp: 12.11.2020). 
grupa Too Much Trouble. Z kolei najbardziej pozytywnie w badaniu prezentuje się sylwetka utworów Dr. Dre ${ }^{77}$. Tekst z 2001 roku Piotr Ratajczak powinien już znać, ale widocznie nie poszukiwał podobnych treści.

Powyższe wyniki badań utwierdzają nas w przekonaniu, iż nienawiść wobec kobiet jest jak najbardziej obecna w tekstach raperów, jednak ich natężenie możemy określić jako stosunkowo niskie. Zbadanie kolejno 403 i 490 ścieżek dźwiękowych, jawi się jako imponująca liczba. Rezultat obu danych naświetla nam nieco zjawisko mizogini.

Powróćmy do sedna tematu. Rok 1980 wydał bardzo ważną treść muzyczną. Właśnie w tamtym czasie ujrzała światło dzienne piosenka The Breaks ${ }^{78}$. Popis Kurtisa Falkera i sprzedaż jego piosenki, jednoznacznie wskazała na pozycje, którą zdobywał rap. Mianowicie owa muzyka stawała się coraz bardziej popularna. Wspomniałem już na wstępie pracy, że The Breaks jest pierwszym trackiem, który uzyskał certyfikat złotej płyty ${ }^{79}$. Czy jesteśmy w stanie stwierdzić, co było miarą sukcesu? Moglibyśmy pokusić się na wskazanie kilku subiektywnych czynników, takich jak głos, osobista charyzma Kurtisa Blowa, czy łatwo wpadająca w ucho melodia.

Ed Piskor, uknucie pseudonimu muzycznemu przypisuje Russelowi „Rush” Simmonsowi, założycielowi wytwórni Def Jef Recordings. Sukces artysty miało przynieść skojarzenie ze słowem Blow, które w slangu amerykańskim miało oznaczać kokainę, kojarzące się ze spożywaniem jej, przez zamożniejsze warstwy tamtejszego społeczeństwa. W ten sposób powstał przydomek Kurtis Blow ${ }^{80}$. Słowo może być przetłumaczony na wiele sposobów (przerwa, złamanie, stłuc, rozrywać). Bardziej sensownie, w kontekście utworu The Breaks wydaje się wskazanie na trudności (podkr. M. Kwiatkowski), z którymi zmagają się na co dzień ludzie.

If your woman steps out with another man

And she runs off with him to Japan

$[\ldots]$

You say last week you met the perfect guy

And he promised you the stars in the sky

He said his Cadillac was gold

But he didn't say it was 10 years old

He took you out to the Red Coach grill

But he forgot the cash and you paid the bill

77 Tamże, s. 126.

78 Kurtis Blow, dz. cyt.

${ }^{79}$ https://www.riaa.com/gold-platinum/?tab_active=default-award\&se=Kurtis+Blow \#search_section (dostęp: 27.10.2020).

${ }^{80}$ E. Piskor, dz. cyt., s. 7. 
Być może na podstawie dość powierzchownej analizy tekstu, sukces kryje się w pewnym humaniźmie artysty, który jest w stanie dostrzec problemy dnia codziennego, ale mówi: „Well, these are the breaks!” (Cóż, to właśnie są trudności), czyli: żyj po swojemu, nie poddawaj się.

\section{Wyniki badań}

Studia nad początkiem rapu w USA, są w Polsce praktycznie nietknięte. Poszczególne informacje w Polsce możemy wyzyskać, dzięki wydaniu kilku encyklopedii, bądź innych, pomocnych tworów literackich. Dużo bardziej pomocne okazały się prace zagraniczne. Badania autora miały pokazać, że kształtująca się wtedy kategoria muzyczna, może być uchwycona jako zjawisko historyczne, wraz z przyczyną i skutkiem. Do tej pory brakuje naukowego opracowania problemu, tj. genezy muzyki rap w Stanach Zjednoczonych, w postaci obszernego tytułu, napisanego przez zawodowego historyka. Materia ta jest o tyle interesująca, że w pewien sposób tłumaczy, dlaczego później nagrywana muzyka w Polsce, mogła być przyjęta jako wyjątkowa.

Zostały obalone stereotypy, orzekające, iż rap był domeną jedynie mężczyzn. Sprawdziliśmy także, jak się okazało, błędne przypisywanie zjawiska mizoginii, dla całej płci męskiej, kultywującej omawiany gatunek muzyczny. Z drugiej strony, zdecydowanie musimy przeciwstawić się potencjalnemu wybielaniu artystów. Branża muzyczna skrywa w sobie wiele tajemnic a artyści nie zawsze byli osobami, pochodzącymi z dobrych domów. Analiza utworów, pochodzących z epoki rapu niezaangażowanego, uwypuklają styl melorecytacji, który wraz z muzyką, charakteryzuje ogólny obraz warstw dźwiękowych, popełnionych przez pierwszych raperów.

\section{BIBLIOGRAFIA}

\section{Źródła muzyczne}

Berry C., And His Combo, Too Much Monkey Business, Chess Record Corp., 1956.

Blow K., The Breaks, Mercury Records, 1980.

Cheba E., Lookin' Good (Shake Your Body), TreeLine Records, 1979.

Chic, Good Times, Antlantic Recording Corporation, 1979.

Clay C., Round 1: „I Am the Greatest”, [w:] I Am the Greatest, Columbia Records, 1963.

Flesh Grandmaster \& The 4 MCs, Live at the Audubon Ballroom, 1978, https://www.youtube. com/watch?v=AupuYHEo2p0 (dostęp: 9.09.2020). 
Funky Four Plus One More, Rapping and Rocking The House, Enjoy Records, 1979.

Gang Sugarhill, Rapper's Delight, Sugarhill Records, 1979.

Gee Spoonie, Sound of New York A Soulful Sound: Spoonin Rap, Queen Constance Records, 1979. Gee Spoonie and The Threacherous Three, The New Rap Language, Enjoy Records, 1980.

Gee Spoonie, Meets The Sequence, Monster Jam, Sugar Hill Records, 1980.

Heron G.S., The Revolution Will Not Be Televised, BGP, 1971.

Markham P., Here Comes The Judge, Chess Producing Corp., 1968.

Marrow T. L., I'm Your Pusher, Sire Records Company, 1988.

Mayfield C., Pusherman, [w:] Superfly, Curtom Records, 1972.

The Sequence, Funk You Up, Sugarhill Records, 1979.

Theodore Grand Wizard, Mean Gene, Live on 3rd Avenue-Ballroom, 1977, https://www.youtube.com/watch?3v-jw3CqFzc0fM (dostęp: 9.09.2020).

\section{Plakaty i bilety}

Bronx River Center, May 30, 1980, https://digital/library,cornell/edu/catalog/ss:1335161 (dostęp: 3.09.2020).

Laurence R., 40 years on from the party where hip hop was born, https://www.bbc.com/culture/article/20130809-the-party-where-hip-hop-was-born (dostęp: 3.09.2020).

Rick James/Grandmaster Flash Kansas City Concert Poster, https://entertainment.ha.com/ $\mathrm{itm} /$ music-memorabilia/posters/rick-james-grandmaster-flash-kansas-city-concertposter-al-haymon-1976-/a/7011-51068.s (dostęp: 28.09.2020).

\section{Opracowania}

Armstrong E.G., Gangsta Misogyny: A Content Analysis of The Portrayals of Violence Against Women In Rap Music, 1987-1993, „Journal of Criminal Justice and Popular Culture” 2001, t. 2, nr 8, https://web.archive.org/web/20120920054843/http://www.albany.edu/scj/ jcjpc/vol8is2/armstrong.html (dostęp: 12.11.2020).

Buda A., Encyklopedia Hip-Hopu, 2005.

Charnas D., The Big Payback: The History of the Business of Hip-Hop, Nowy Jork 2011.

Edwards P., How to Rap: The Art \& Science of the Hip-Hop MC, Chicago 2009.

Generation The Younger, We Rap More Mellow, Brass Records, 1979.

Harrison A. K., Arthur C.E., The Foundations Of Hip-Hop Encyclopedia, Blacksburg 2019.

Henderson E.A., Black Nationalism and Rap Music, „Journal of Black Studies” 1996, t. 26, nr 3. Miszczak R., Cała A., Beaty Rymy Życie: Leksykon Muzyki Hip-Hop, Poznań 2005.

Muray F., Neal M.A., That's The Joint! The Hip-Hop Studies Reader, Nowy Jork 2004.

Piskor E., Hip Hop Genealogia, cz. 1, Warszawa 2018.

Riggs T., African Hip-Hop, [w:] The St. James Encyclopedia of Hip Hop Culture, Farmington Hills 2018.

Sköld D., Rehn A., Makin' It, by Keeping It Real: Street Talk, Rap Music, and the Forgotten Entrepreneurship From „The Hood”, „Group \& Organization Management” 2007, t. 32, nr 1.

Weitzer R., Kubrin C.E., Misogny in Rap Music: A Content Analysis of Prevalence and Meanings, „Men and Masculinites” 2009, t. 12, nr 1. 


\section{Źródła internetowe}

Billboard 200, Chart History, Curtis Mayfield, https://www.billboard.com/music/curtis-mayfield/chart-history/TLP/song/376012 (dostęp: 17.09.2020).

Blumberg S., The 90 raw: Gill Scott-Heron, https://mediaburn.org/video/the-90s-raw-gilscott-heron/ (dostęp: 16.09.2020).

Did Pigmeat Realase first hip-hop song, https://www.xxlmag.com/did-pigmeat-markhamrelease-the-first-hip-hop-song/ (dostęp: 16.09.2020).

Official Singles Chart Results Matching: Here Comes The Judge, https://www.officialcharts. com/search/singles/here\%20comes\%20the\%20judge/ (dostęp: 16.09.2020).

Wygląd winylowego singla Chucka Berrego, http://www.45worlds.com/78rpm/record/1635 (dostęp: 8.10.2020).

Wyróżnienie singla „The Breaks” przez Recording Industry Association of America (RIAA), https://www.riaa.com/gold-platinum/?tab_active=defaultaward\&se=Kurtis+Blow\#sea rch_section (dostęp: 27.10.2020).

\section{Filmografia}

Marrow T. L., Something From Nothing: The Art of Rap, 2012.

Pray D., Scratch, 2001.

Wheler D., Bascuñán R., Ewolucja Hip-Hopu: Początek, Netflix 2016.

\section{Słowniki}

Ratajczak P., Hip-Hop: słownik angielsko-polski, Zielona Góra 2006.

Maciej Kwiatkowski

\section{THE ART OF MELODECLAMATION STUDIES ON THE ORIGIN OF RAP MUSIC}

$\mathrm{T}^{\mathrm{s}-1}$ he article focus on problematic associated with beggining of rap music. Studying oldest songs from genre showing, that in most instances, people rapping for fun or to encourage other in participation in it. Author probe not only first rap songs and rap artists, but also music extraction, which arise from inspiration some type of music, like blues, funk, or jazz. Analise few singles from 70. and 80. trying answer on question, why some tracks were so popular. By specyfic of subject, text vicariously keeping on city culture of New York, previous century in United States

Keywords: past, origins, culture, rap, scratch. 